\title{
HUBUNGAN LAMANYA WAKTU PENGGUNAANTABLET COMPUTERDENGAN KELUHAN PENGLIHATANPADA ANAK SEKOLAH DI SMP Kr. EBEN HEAZER 2 MANADO
}

\author{
${ }^{1}$ Jurisna Maria Pangemanan \\ ${ }^{2} J$. S. M. Saerang \\ ${ }^{2}$ Laya. M. Rares \\ ${ }^{1}$ Kandidat Skripsi Fakultas Kedokteran Universitas Sam Ratulangi \\ ${ }^{2}$ Bagian Ilmu Kesehatan Mata RSU Prof. R. D . Kandou, Malalayang Manado \\ Email: jmpangemanan@yahoo.co.id
}

\begin{abstract}
Growing technologicl advances to facilitate each person in their employment and work to resolve the majority of the work is done by eyes when using a tablet computer. So, often school students have complaint in the eyes for the result in too long concentration in tablet computer as a result of it's electromagnetic waves radiation and can disturb the health of the eyes resulting in impaired vision. For it must be known that factors relating to the complaint vision such as gender, age, time of use in a day. This research is descriptive cross sectional analytic method. The population of school children in the study was all students grade 2 of the Eben Haezer Christian Junior High 2 Manado totaling in 136 people. The sample was 70 people. The research data is obtained by using a questionnaire that is filled by school children to determine the relationship of duration of use of a tablet computer with visual complaints using chi-square statistical test. Results of chi-square statistical test showed no significant relationship between duration of use tablet computers with complaints of vision that is at the level $(<\mathrm{n}=0.005)$. in the complaint vision watery eyes feel the chi-square test results with significant level $(\mathrm{n}=0.005)<(\mathrm{n}=0.003)$. this means that there is a significant relationship correlation with the duration of use tablet computers with vision complaints that the complaint was watery eyes. Bassed on this research it is advised at that tablet computer users to give time for the eye to rest, blink often and tend to check-up their eyes condition Keywords: computer usage time, impaired vison.
\end{abstract}

\begin{abstract}
Abstrak: Kemajuan teknologi semakin berkembang sehingga mempermudah setiap oarng dalam bekerja menyelesaikan pekerjaannya dan sebagian besar pekerjaan dilakukan oleh mata pada saat menggunakan tablet computer. Sehingga tak jarang anak sekolah mengalami keluhan pada mata akibat terlalu lama berkonsentrasi pada monitor tablet computer dan gelombang elektromagnetik yang dihasilkan oleh monitor inimenghasilkan radiasi dan bisa menggangu kesehatan mata yang menyebabkan keluhan penglihatan. Untuk itu perlu diketahui faktor-faktor yang berhubungan dengan keluhan penglihatan seperti jenis kelamin, faktor usia, lama penggunaan dalam sehari, waktu jeda, cara penggunan tablet computer, keseimbangan pencahaan ruangan dan monitor. Penelitian yang dilakukan bersifat deskriptif analitik dengan metode cross sectional. Populasi dalam penelitian adalah anak sekolah seluruh siswa-siswi kelas 2 SMP Kr. Eben Haezer 2 Manado yang berjumlah 136 orang.Sampel dalam penelitian ini berjumlah 70 orang. Data penelitian ini data penelitian ini didapat dengan menggunakan kuesioner yang diisi oleh anak sekolah untuk mengetahui hubungan lamanya penggunaan tablet computer dengan keluhan penglihatan dengan menggunakan uji statistik chi-square. Hasil uji statistic chi-square menunjukkan ada hubungan yang signifikan antara lamanya penggunaan tablet computer dengan keluhan penglihatan yaitu pada taraf $(<\mathrm{n}=0,005)$. Pada keluhan penglihatan mata terasa berair hasil uji chi-squaredengan taraf signifikan $(\mathrm{n}=0.005)<(\mathrm{n}=0.003)$. ini berarti ada hubungan yang signifikan dengan lamanya penggunaan tablet computerdengan keluhan penglihatan yaitu pada keluhan mata terasa berair. Berdasarkan penelitian ini disarankan bagi para penguna tablet computeruntuk upayakan melakukan istirahat mata, mengediplah lebih sering dan melakuakn pemeriksaan mata.
\end{abstract}

Kata kunci: waktu pengunaan laptop, keluhan penglihatan.

Mata adalah salah satu alat indera penglihatan yang terdapat pada manusia yang diciptakan oleh Tuhan dan merupakan organ terpenting pada manusia.Dengan menggunakan mata manusia dapat melihat lingkungan yang ada disekitarnya, sehingga 
manusia bisa mampu memperoleh informasi yang terpercaya dan akurat.

American Optometric Association (AOA) mendefinisikan Computer Vision Syndrome (CVS) sebagai masalah mata majemuk yang berkaitan dengan pekerjaan jarak dekat yang dialami seseorang selagi atau berhubungan dengan penggunaan komputer. $^{1,2}$

Keluhan penglihatan ini merupakan masalah pada masyarakat yang akan selalu dijumpai. Jika sering terjadi kelainan keluhan penglihatan, ini akan berdampak terjadinya kelainan refraksi. Hal ini berkaitan dengan Computer Vision Syndrom (CVS), karena masalah mata yang disebabkan oleh seseorang yang penggunaan komputernya dengan jarak mata yang dekat. ${ }^{1,2}$,

Perkembangan teknologi saat ini memungkinkan manusia untuk lebih sering menggunakan teknologi dalam kehidupannya. ${ }^{4}$ Kemajuan akhir-akhir ini menghasilkan begitu banyak tablet computer yang canggih. Banyak konsumen yang seprtinya terbuai dengan fitur-fitur menarik yang disediakan oleh produsen-produsen tablet computer tersebut. Dengan mudahnya kita bisa melihat bahwa hampir semua orang memiliki sebuah tablet computer bahkan adapula yang memiliki lebih dari satu. Dibalik itu semua para konsumen telah melupakan satu hal penting yaitu apa dampak negative dari penggunaan tablet computer. Semakin sering mata kita berkonsentrasi dilayar tablet computer maka dapat menimbulakn masalah kesehatan yaitu baik secara fisik dan mental pada operatornya. Ada begitu banyak gangguan yang disebabkan, diantaranya adalah keluhan penglihatan.

Ketidaknyamanan dan gangguan kesehatan sering dikeluhkann pengguna komputer. Survei yang dilakukan oleh America Optometrist Associatiom (AOA) menunjukkan bahwa lebih dari 10 juta pemeriksaan mata pertahun di Amerika Serikat dilakukan untuk masalah penglihatan oleh penggunaan perangkat elektronik. ${ }^{3}$

Visual Display Terminal (VDT) atau yang biasanya disebut monitor adalah bagian yang biasanya ditatap dan menimbulkan gangguan kesehatan mata pada penggunanya. ${ }^{3}$ Jika dilihat dari penggunaannya,penggunaan tablet computer semakin menjadi paling banyak digemari. Hal ini dikarenakan hargatablet computer yang semakin terjangkau. Di segi lain penggunaan tablet computer ini lebih fleksibel karena memudahkan para pengguna untuk dibawa kemana-mana. ${ }^{3}$

\section{METODOLOGI}

Metode yang diterapkan dalam penelitian ini adalah bersifat survey analitik dengan menggunakan desain potong lintang (cross secrional) dengan sifat observasional.

Kriteria inklusi pada pengambilan sampel, yaitu siswa kelas VIII, jenis kelamin pria dan wanita, tidak dalam kondisi sakit mata atau cacat mata dan bersedia sebagai objek penelitian sampai selesai dengan menandatangani informed consent

Penelitian ini menggunakan kuesioner dengan menggunakan pertanyaan terstruktur dan dilakukan pemeriksaan visus untuk menentukan jenis kelainan refraksi. Untuk melihat adanya hubungan antara variabel terikat dan variabel bebas maka digunakan uji Chi Square test dengan tingkat signifikan $5 \%(0,05)$.

\section{HASIL PENELITIAN}

Penelitian dilakukan di SMP Kr. EbenHaezer 2 Manado dengan jumlah siswa sebanyak 163 orang dan sampel berjumlah 70 orang didapatkan hasil sebagai berikut:

Tabel 1. Distribusi frekuensi alat bantuyang digunakan

\begin{tabular}{ccc}
\hline Karakteristik & $\mathbf{F}($ orang) & $\mathbf{\%}$ \\
\hline Pengguna lensa kontak & & \\
YA & 2 & 2.9 \\
TIDAK & 68 & 97.1 \\
Total & $\mathbf{7 0}$ & $\mathbf{1 0 0 . 0}$ \\
\hline PenggunPengguna & & \\
kacamata & & 11.4 \\
YA & 8 & 88.6 \\
\hline TIDAK & 62 & $\mathbf{1 0 0 . 0}$ \\
\hline Total & $\mathbf{7 0}$ &
\end{tabular}


kelas VIII SMP Kr. Eben Haaezer 2 Manado sebanyak 163 siswa.

Populasi dari penelitian ini adalah siswa Sampel berjumlah 70 orang yang akan dipilih untuk menjadi subjek penelitian berdasarkan kriteria yang sudah ditetapkan dengan teknik pengambilan sampel secara acak sederhana (simple random sampling).

Berdasarkan tabel diatas menunjukkan bahwa responden dalam penelitian ini lebih banyak yang menggunakan alat bantu penglihatanf jenis kacamata, yaitu sebanyak 8 orang (11.4\%) dan responden yang menggunakan alat bantu penglihatanjenis lensa kontak lebih sedikit, yaitu sebanyak 2 orang (2.9\%).

Tabel 2. Distribusi jenis lensa yang digunakan

\begin{tabular}{|c|c|c|}
\hline Karakteristik & $\mathbf{F ( o r a n g )}$ & $\%$ \\
\hline \multicolumn{3}{|l|}{$\begin{array}{c}\text { Jenis AB } \\
\text { penglihatan } \\
\text { yang digunakan }\end{array}$} \\
\hline $\begin{array}{c}\text { Kacamata lensa } \\
\text { (M) }\end{array}$ & 1 & 12.5 \\
\hline $\begin{array}{c}\text { Kacamata lensa } \\
\text { (P) }\end{array}$ & - & - \\
\hline $\begin{array}{c}\text { Kacamata lensa } \\
\text { (S) }\end{array}$ & 1 & 12.5 \\
\hline $\begin{array}{c}\text { Kacamata lensa } \\
(\mathrm{M} / \mathrm{S})\end{array}$ & 4 & 50.0 \\
\hline Lensa kontak & - & - \\
\hline$(\mathrm{M})$ & - & - \\
\hline Lensa kontak (P) & - & - \\
\hline \multicolumn{3}{|l|}{ Lensa kontak (S) } \\
\hline $\begin{array}{l}\text { Lensa kontak } \\
(\mathrm{M} / \mathrm{S})\end{array}$ & - & - \\
\hline $\begin{array}{l}\text { Kacamata lensa } \\
\text { (M) + Lensa } \\
\text { kontak (M) }\end{array}$ & 2 & 25.0 \\
\hline $\begin{array}{c}\text { Kacamata lensa } \\
\text { (P) + Lensa } \\
\text { kontak (P) }\end{array}$ & - & - \\
\hline $\begin{array}{l}\text { Kacamata lensa } \\
\text { (S) + Lensa } \\
\text { kontak (S) }\end{array}$ & - & - \\
\hline $\begin{array}{c}\text { Kacamata lensa } \\
(\mathrm{M} / \mathrm{S})+\text { Lensa } \\
\text { kontak }(\mathrm{M} / \mathrm{S})\end{array}$ & - & - \\
\hline Total & 8 & 100.0 \\
\hline
\end{tabular}

Dari Tabel 2 dapat dilihat distribusi responden yang menggunakan alat bantu penglihatan 8 orang diantaranya menggunakan alat bantu penglihatan, jenis lensa yang digunakan terdapat kacamata lensa (M/S), kacamata (M), Kacamata (S) adapun responden yang menggunakan kacamata + lensa kontak (M).

Tabel 3. Distribusi frekuensi perangkat elektronik yang sering digunakan dan cara penggunaan

\begin{tabular}{ccc}
\hline Karakteristik & F(orang) & \% \\
\hline $\begin{array}{c}\text { Perangkat elektronik } \\
\text { yang sering } \\
\text { digunakan } \\
\text { Yang menggunakan } \\
\text { tablet computer } \\
\text { Tidak menggunakan } \\
\text { tablet computer } \\
\text { yang menggunakan } \\
\text { smartphone }\end{array}$ & 28 & 40.0 \\
\hline Total & 16 & 37.1 \\
\hline $\begin{array}{c}\text { Cara penggunaan } \\
\text { tablet computer }\end{array}$ & $\mathbf{7 0}$ & $\mathbf{1 0 0 . 0}$ \\
\hline Posisi duduk & 14 & 50.0 \\
\hline Posisi tidur tengkurap & 14 & 50.0 \\
\hline Total & $\mathbf{2 8}$ & $\mathbf{1 0 0 . 0}$ \\
\hline
\end{tabular}

Dapat terlihat pada Tabel 3 bahwa dari 70 responden tidak semua sering menggunakan tablet computer, responden yang sering menggunakan elektronik dengan jenis tablet computer lebih banyak, tapi perbandingan tidak jauh berbeda dengan responden yang menggunakan tablet computer, adapun responden yang hanya menggunakan smartphone. Sedangkan cara penggunaan tablet computer terlihat perbandingannya sama.

Berdasarkan Tabel 4 dapat dilihat bahwa perbandingannya responden dalam penelitian ini lebih banyak yang menggunakan tablet computer lebih dari 2 tahun, sedangkan $1-2$ tahun dan $<1$ tahun perbandingan tidak jauh berbeda juga jumlah respondennya sedikit . 
Jurnal e-CliniC (eCl), Volume 2, Nomor 2, Juli 2014

Tabel 4. Distribusi frekuensi riwayat penggunaan tablet computer

\begin{tabular}{ccc}
\hline Karakteristik & F(orang) & \% \\
\hline $\begin{array}{c}\text { Riwayat } \\
\text { penggunaan tablet } \\
\text { computer } \\
\text { Kurang dari } 1 \text { tahun }\end{array}$ & 2 & 7.1 \\
$1-2$ tahun & 9 & 32.1 \\
Lebih dari 2 tahun & 17 & 60.7 \\
\hline Total & $\mathbf{2 8}$ & $\mathbf{1 0 0 . 0}$ \\
\hline
\end{tabular}

Tabel 5. Distribusi frekuensi lamanya penggunaan tablet computerrata - rata dalam sehari

\begin{tabular}{ccc}
\hline karakteristik & F(orang) & \% \\
\hline $\begin{array}{c}\text { Lama penggunaan tablet } \\
\text { computer/ hari } \\
\text { Kurang dari } 1 \text { jam }\end{array}$ & 3 & 10.7 \\
1 - 2 jam & 4 & 14.3 \\
2 - 3 jam & 14 & 50.0 \\
Lebih dari 4 jam & 7 & 25.0 \\
\hline Total & $\mathbf{2 8}$ & $\mathbf{1 0 0 . 0}$ \\
\hline
\end{tabular}

Berdasarakan Tabel 5 terlihat bahwa penggunaan tablet computer rata-rata dalam sehari paling banyak digunakan oleh responden adalah 2-3 jam yaitu sebanyak 14 orang (50.0\%), dan lebih dari 4 jam sebanyak (25.0\%), sedangkan lama penggunaan 1-2 jam sebanyak 4 orang (14.3\%) dan kurang dari 1 jam sebanyak 3 orang (10.7\%)

\section{LAMA PENGGUNAAN TABLET \\ COMPUTER RATA-RATA DALAM SEHARI}

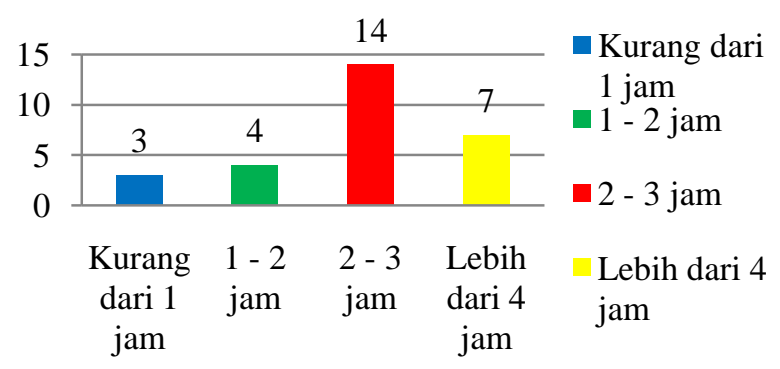

Gambaran 1. Distribusi frekuensi lama penggunaan tablet computer rata - rata dalam sehari

Tabel 6. Distribusi frekuesnsi jeda waktu penggunaan tablet computer dalam sehari dan lama waktu jeda dalam penggunaan tablet computer

\begin{tabular}{ccc}
\hline Karakteristik & F(orang) & \% \\
\hline $\begin{array}{c}\text { Jeda waktu penggunaan } \\
\text { tablet computer }\end{array}$ & & \\
YA & 23 & 82.1 \\
TIDAK & 5 & 17.9 \\
\hline Total & $\mathbf{2 8}$ & $\mathbf{1 0 0 . 0}$ \\
\hline Waktu jeda dalam & & \\
menggunakan tablet & & \\
computer & & \\
\hline TIDAK ADA JEDA & 5 & 17.9 \\
1 - 5 MENIT & 2 & 7.1 \\
5 - 10 MENIT & 5 & 17.9 \\
$10-$ 15 MENIT & 5 & 17.9 \\
$15-20$ MENIT & 11 & 39.3 \\
\hline Total & $\mathbf{2 8}$ & $\mathbf{1 0 0 . 0}$ \\
\hline
\end{tabular}

Berdasarakan hasil distribusi Tabel 6 Terbanyak responden menggunakan tablet computer memiliki waktu jeda dan waktu jeda yang sering digunakan 15 - 20 menit 
Pangemanan, Saerang, Rares; Hubungan Lamanya Waktu Penggunaan Tablet...

\section{WAKTU JEDA SAAT \\ MENGGUNAKAN TABLET COMPUTER}

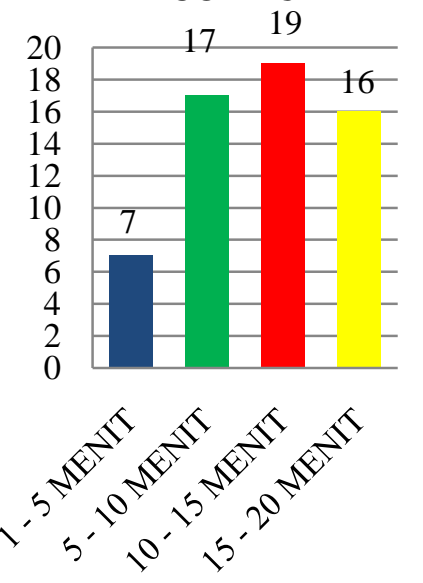

1 - 5 MENIT

- 5 - 10 MENIT

$\square 10-15$

MENIT

$15-20$

MENIT

Gambar 2. Distribusi frekuensi waktu jeda saat menggunakan tablet computer

Tabel 7. Distribusi lamanya waktu saat mulai merasakan keluhan

\begin{tabular}{ccc}
\hline Karakteristik & $\mathbf{F ( o r a n g )}$ & $\mathbf{\%}$ \\
\hline $\begin{array}{c}\text { Waktu mulai } \\
\text { merasakan keluhan }\end{array}$ & & \\
Tidak ada waktu keluhan & 1 & 3.6 \\
kurang dari 1 jam & 6 & 21.4 \\
$1-2$ jam & 5 & 17.9 \\
$2-3$ jam & 15 & 53.6 \\
Lebih dar 4 jam & 1 & 3.6 \\
\hline Total & $\mathbf{2 8}$ & $\mathbf{1 0 0 . 0}$ \\
\hline
\end{tabular}

Tabel 8. Distribusi frekuensi pencahayaan ruangan dengan tampilan tablet computer dan besar daya lampu yang digunakan untuk pencahayaan ruangan

\begin{tabular}{ccc}
\hline Karakteristik & $\mathbf{F}($ orang) & $\mathbf{\%}$ \\
\hline $\begin{array}{c}\text { Keseimbangan } \\
\text { pencahayaan tablet } \\
\text { computer dengan } \\
\text { pencahayaan ruangan } \\
\text { YA }\end{array}$ & & \\
TIDAK & 19 & 67.9 \\
Total & 9 & 32.1 \\
\hline Besar daya lampu yang & $\mathbf{2 8}$ & $\mathbf{1 0 0 . 0}$ \\
digunakan untuk & & \\
pencahayaan ruangan & & \\
\hline 20 WATT & 9 & 32.1 \\
$>$ 20 WATT & 19 & 67.9 \\
\hline Total & $\mathbf{2 8}$ & $\mathbf{1 0 0 . 0}$ \\
\hline
\end{tabular}

Dapat dilihat pada Tabel 7 dari 28 responden bahwa hanya 27 orang yang memiliki waktu mulai merasakan keluhan penglihatann, dilihat juga dari lama penggunaan tablet computerdan terbanyak responden mulai merasakn keluhan pada saat 2 - 3 jam menggunakan tablet computer.

\section{LAMA WAKTU MULAI MERASAKAN KELUHAN}

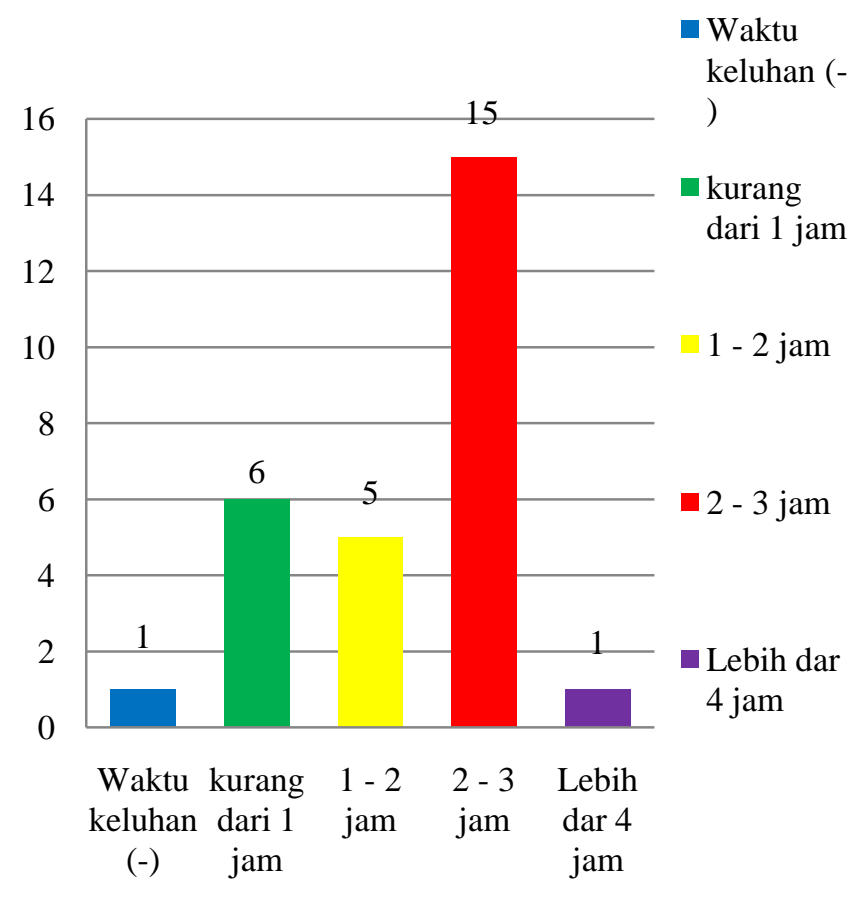

Gambaran 3. Distribusi frekuensi lama waktu menggunakan tablet computer

Dapat dilihat pada Tabel 8 terbanyak responden mengalami keluhan dengan keseimbangan pencahayaan tablet computer dengan pencahayaan ruangan, serta lampu pencahayaan yang digunakan kebanyak memilih lampu $>20$ watt. 
Tabel 9. Distribusi frekuensi keluhan penglihatan melebihi dari satu keluhan

\begin{tabular}{|c|c|c|}
\hline Karateristik & F(orang) & $\%$ \\
\hline $\begin{array}{l}\text { Keluhan pada mata saat } \\
\text { menggunakan tablet } \\
\text { computer }\end{array}$ & & \\
\hline Mata terasa berair & 1 & 3.6 \\
\hline $\begin{array}{l}\text { Mata terasa ada benda } \\
\text { asing }\end{array}$ & 1 & 3.6 \\
\hline $\begin{array}{l}\text { gatal, kering, nyeri, } \\
\text { tegang, benda asing, } \\
\text { sakit kepala }\end{array}$ & 1 & 3.6 \\
\hline $\begin{array}{l}\text { gatal, kering, berair, } \\
\text { kabur, sakit kepala }\end{array}$ & 1 & 3.6 \\
\hline kering, tegang & 1 & 3.6 \\
\hline $\begin{array}{l}\text { gatal, kering, nyeri, } \\
\text { tegang, benda asing, } \\
\text { kabur, sakit kepala }\end{array}$ & 1 & 3.6 \\
\hline kering, tegang, kabur & 1 & 3.6 \\
\hline $\begin{array}{l}\text { gatal, berair, kabur, sakit } \\
\text { kepala }\end{array}$ & 1 & 3.6 \\
\hline gatal, tegang, berair & 1 & 3.6 \\
\hline $\begin{array}{l}\text { tegang, silau, sakit } \\
\text { kepala }\end{array}$ & 1 & 3.6 \\
\hline kering, nyeri & 1 & 3.6 \\
\hline $\begin{array}{l}\text { gatal, tegang, kabur, } \\
\text { sakit kepala }\end{array}$ & 1 & 3.6 \\
\hline gatal, kering, tegang & 1 & 3.6 \\
\hline gatal, nyeri, tegang & 1 & 3.6 \\
\hline $\begin{array}{l}\text { gatal, tegang, kabur, } \\
\text { sakit kepala }\end{array}$ & 1 & 3.6 \\
\hline $\begin{array}{l}\text { gatal, kering, tegang, } \\
\text { benda asing, kabur }\end{array}$ & 1 & 3.6 \\
\hline $\begin{array}{l}\text { kering, nyeri, tegang, } \\
\text { berair, sakit kepala }\end{array}$ & 1 & 3.6 \\
\hline $\begin{array}{l}\text { nyeri, tegang, kabur, } \\
\text { sakit kepala }\end{array}$ & 1 & 3.6 \\
\hline $\begin{array}{l}\text { tegang, kabur, sakit } \\
\text { kpala }\end{array}$ & 1 & 3.6 \\
\hline $\begin{array}{l}\text { gatal, kering, tegang, } \\
\text { lelah }\end{array}$ & 1 & 3.6 \\
\hline gatal, sakit kepala & 1 & 3.6 \\
\hline $\begin{array}{l}\text { gatal, tegang, sakit } \\
\text { kepala }\end{array}$ & 1 & 3.6 \\
\hline $\begin{array}{l}\text { gatal, nyeri, tegang, } \\
\text { benda asing, sakit } \\
\text { kepala }\end{array}$ & 1 & 3.6 \\
\hline $\begin{array}{l}\text { gatal, tegang, berair, } \\
\text { silau, sakit kepala }\end{array}$ & 1 & 3.6 \\
\hline $\begin{array}{l}\text { gatal, nyeri, tegang, } \\
\text { berair, benda asing, } \\
\text { silau, kabur }\end{array}$ & 1 & 3.6 \\
\hline $\begin{array}{l}\text { benda asing, sakit } \\
\text { kepala }\end{array}$ & 1 & 3.6 \\
\hline $\begin{array}{l}\text { kering, nyeri, tegang, } \\
\text { berair, benda asing, } \\
\text { silau, kabur, sakit kepala }\end{array}$ & 1 & 3.6 \\
\hline $\begin{array}{l}\text { gatal, kering, berair, } \\
\text { kabur, sakit kepala }\end{array}$ & 1 & 3.6 \\
\hline $\begin{array}{c}\text { Total } \\
\end{array}$ & 28 & 100.0 \\
\hline
\end{tabular}

Hasil penelitian ini melaporkan bahwa gejala keluahan pada mata yang dialami responden, memberikan dampak lebih dari 2 gejala untuk keluhan pada mata, dan dari 28 responden ada 2 responden yang hanya mengalami 1 gejala yaitu mata terasa berair sebanyak 1 orang (3.6\%), dan mata terasa seperti ada benda asing sebanyak 1 orang (3.6\%).

Tabel 10. Distribusi frekuensi keluhan penglihatan terbanyak

\begin{tabular}{|c|c|c|c|}
\hline Karakteristik & F(orang) & & Total \\
\hline & $\mathrm{Y}$ & $\mathrm{T}$ & \\
\hline $\begin{array}{c}\text { Keluhan } \\
\text { pengliahatn }\end{array}$ & & & \\
\hline $\begin{array}{c}\text { Mata terasa } \\
\text { Gatal }\end{array}$ & 16 & 12 & 28 \\
\hline$\%$ & 57.1 & 42.9 & 100.0 \\
\hline $\begin{array}{l}\text { Mata terasa } \\
\text { Kering }\end{array}$ & 8 & 20 & 28 \\
\hline$\%$ & 28.6 & 71.4 & 100.0 \\
\hline $\begin{array}{l}\text { Mata terasa } \\
\text { Nyeri }\end{array}$ & 9 & 19 & 28 \\
\hline$\%$ & 32.1 & 67.9 & 100.0 \\
\hline Sakit kepala & 14 & 14 & 28 \\
\hline$\%$ & 50.0 & 50.0 & 100.0 \\
\hline $\begin{array}{l}\text { Mata terasa } \\
\text { Berair }\end{array}$ & 13 & 15 & 28 \\
\hline$\%$ & 46.4 & 53.6 & 100.0 \\
\hline $\begin{array}{c}\text { Mata terasa } \\
\text { Silau }\end{array}$ & 14 & 14 & 28 \\
\hline$\%$ & 50.0 & 50.0 & 100.0 \\
\hline $\begin{array}{c}\text { Mata terasa } \\
\text { Tegang/ Lelah }\end{array}$ & 18 & 10 & 28 \\
\hline$\%$ & 64.3 & 35.7 & 100.0 \\
\hline $\begin{array}{c}\text { Mata terasa } \\
\text { Kabur/ } \\
\text { Bayang }\end{array}$ & 11 & 17 & 28 \\
\hline$\%$ & 39.3 & 60.7 & 100.0 \\
\hline $\begin{array}{c}\text { Mata terasa } \\
\text { Kabur/ } \\
\text { Bayang } \\
\end{array}$ & 11 & 17 & 28 \\
\hline$\%$ & 39.3 & 60.7 & 100.0 \\
\hline
\end{tabular}

Dapat dilihat pada tabel 10 keluhan penglihatan yang dapat dialami responden dan keluhan yang tersering dialami responden yaitu keluhan mata terasa tegang dan lelah.

Tabel 11. Hubungan lamanya penggunaan tablet computer dengan keluhan penglihatan 
Pangemanan, Saerang, Rares; Hubungan Lamanya Waktu Penggunaan Tablet...

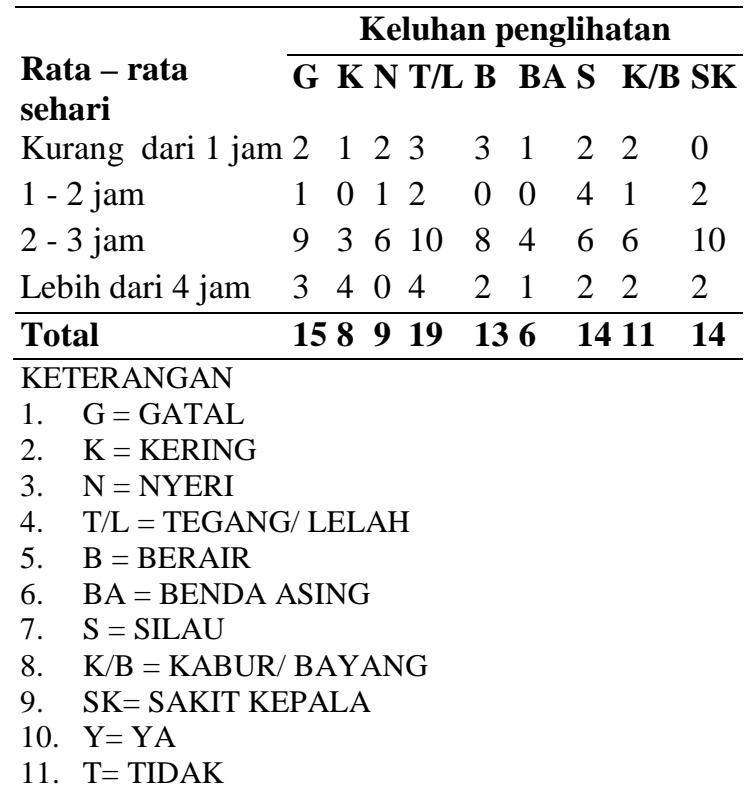

Hasil analisis bivariate mengenai hubungan antara riwayat penggunaan tablet computer dengan keluhan penglihatan didapatkan nilai $p$ untuk salah satu keluhan penglihatan mendapat nilai $(p=0.037)$ yaitu keluhan penglihatan dangan mata terasa berair, ini juga menunjukkan bahwa adanya hubungan yang signifikan terhadap lamanya penggunaan tablet computer dalam sehari dengan keluhan penglihatan pada mata terasa berair.

\section{BAHASAN}

Hasil studi pendahuluan menunjukkan lebih dari sebagian respondenmengeluhkan adanya gejala kelelahan mata. Berdasarkan National Institute forOccupational Safety and Health (NIOSH) (1999), gejala keluhan kelelahan mata ditandai dengan mata merah, berair, perih, gatal/kering, mengantuk, tegang,pandangan kabur, penglihatan rangkap, sakit kepala, dan kesulitan fokus. ${ }^{5}$ Rangkaian keluhan yang diawali dengan adanya keluhan kelelahan mata tersebut sering disebut dengan Computer Vision Syndrome (CVS). ${ }^{6}$ Pada penelitian ini sejalan dengan penelitian sebelumnya responden banyak mengeluhkan keluhan mata tegang/ lelah.

Penelitian di University of South Carolina mengkategorikan penggunaan komputer menjadi tiga kategori yaitu ringan (kurang dari 2 jam), sedang (2-4 jam), dan berat (lebih dari 4 jam) per hari. Penelitian Taylor (2007), di 16 negara di dunia menunjukkan rata-rata lama penggunaan komputer per harinya adalah sekitar 5 jam. Penelitian Sen et al (2007) menunjukkan hampir setengah daripengguna komputer menggunakan komputer secara terusmenerus tanpa istirahat lebih dari 2 jam per harinya. Penelitian Hoesin et al (2007) di 16 kota di Indonesia menunjukkan rata-rata penggunaan komputer di Indonesia kurang dari 5 jam per hari. Di Bantul, 7 \% pengguna komputer menggunakan komputer dalam intensitas yang rendah, $3 \%$ dengan intensitas sedang, $83 \%$ dengan intensitas tinggi (Indriawati et al, 2008). Penelitian Dewi et al (2009) di kantor Samsat Palembang menunjukkan $75 \%$ pekerja menggunakan komputer lebih dari 4 jam. $^{7}$

Sejalan dengan penelitian sebelumnya di Indonesia, pada penelitian ini didapatkan bahwa siswa-siswi SMP Kr Eben Haezer 2 Manado paling banyak menggunakan tablet computer yaitu lebih dari 2 tahun $(60,7 \%)$ dengan rata-rata dalam sehari adalah 2-3 jam (50.0 \%) dan lebih banyak mengalami kleuhan mata terasa tegang atau lelah.

Penelitian Bhanderi et al. yang melaporkan bahwa angka kejadian CVS lebih tinggi pada pengguna VDT yang bekerja secara terus-menerus dalam sehari. Seorang individu yang bekerja di depan komputer selama lebih dari atau sama dengan 4 jam secara terus-menerus berisiko dua puluh enam kali lipat menderita CVS dibandingkan dengan bekerja di depan komputer selama kurang dari 4 jam secara terus-menerus. ${ }^{4}$

NIOSH (1981) dan OSHA (1997) menganjurkan setiap 2 jam menggunakan komputer maka seorang pengguna komputer

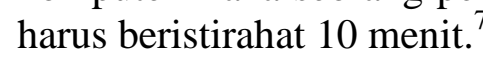

Waktu jeda juga mempengaruhi terjadinya keluhan penglihatan. Pada penelitian ini responden menyediakan waktu jeda yang paling banyak $10-15$ menit (42,5\%). Pada penelitian sebelumnya, lama istirahat selama kurang dari 10 menit setelah terpapar layar monitor berisiko dua puluh kali lipat menderita CVS dibandingkan 
dengan istirahat selama lebih dari atau sama dengan 10 menit. Hal ini sesuai dengan teori dan penelitian sebelumnya oleh Ye et al. yang menyatakan bahwa istirahat selama 1015 menit setelah penggunaan komputer merupakan faktor protektif terhadap munculnya keluhan CVS sedangkan tidak menyempatkan istirahat merupakan faktor risiko dengan odds ratio sebesar 5,1. ${ }^{4}$

\section{SIMPULAN}

Hasil penelitian pada SMP $\mathrm{Kr}$ Eben Haezer 2 Manado.Responden terbanyak tidak menggunakan kacamata, tidak semua menggunakan tablet computer, perbandigan sama pada posisi menggunakan tablet computer yaitu posisi duduk dan tidur tengkurap memiliki jumlah yang sama sebanyak 14 responden (50.0\%).

Pada riwayat penggunaan tablet computer rata-rata yang terbanyak lebih dari 2 tahun Dan rata-rata per hari yang terbanyak 2-3 jam. Responden menggunakan waktu jeda rata-rata 15-20 menit Hal ini yang menyebabkan timbulnya keluhan penglihatan pada mata.

Dari 28 responden, kebanyakkan memilih untuk mengistirahatkan mata atau menggunakan jeda saat menggunakan tablet computer yaitu rata-rata terbanyak 15-20 menit Saat menggunakan tablet computer dengan waktu 2-3 jam rata-rata responden sudah mulai mengalami keluhan penglihatan pada mata Responden memiliki keluhan keseimbangan pencahayaan terhadap pencahayaan ruangan dengan pencahayaan tablet computer dan kebanyakkan responden memakai pencahayaan ruangan lebih dari 20 wat. Dari keluhan penglihatan yang ada, kebanyakkan responden mengalami lebih dari 1 keluhan.

Rata-rata keluhan yang terbanyak dialami responden, mengalami keluahn rasa tegan atau lelah pada mata.

\section{SARAN}

Untuk peneliti yang akan datang yang ingin melakukan penelitian tentang hubungan tablet computer, agar dapat menggali keluhan pada mata dan keluhan pada kesehatan tubuh manusia mengingat dampaknya radiasi dari tablet computer bila kita sering terpapar. Dan bagi pengguna tablet computer gunakan waktu jeda untuk mengistirahatkan mata sejenak agar dapat mengurangi keluhan yang dialami dan perbanyaklah mengkonsumsi buah dan sayuran mengandung vit.A serta melakukan pemeriksaan mata 6 bulan/sekali atau 3 bulan/sekali.

\section{DAFTAR PUSTAKA}

1. American Optometric Association. Computer Vision Syndrome. 2013 (cited; 2013 Sept 19). Available from http://www.aoa.org/x5374.xml

2. Affandi ES. Sindrom Penglihatan Komputer. Majalah kedokteran indoneseia. (cited 2013 Sept 19) 2005; 55(3): 297-300

3. Aryanti Citra. Hubungan Lama Penggunaan Komputer Dengan Sindrom Mata Kering. (Skripsi) Medan: USU; 2011

4. Azkadina A. Hubungan antara faktor risiko individual dan komputer terhadap kejadian computer vision syndrome. [Skripsi] Semarang : UNDIP ; 2012.

5. Maryam Siti. Faktor-faktor yang berhubungan dengan keluhan kelelahan mata pada pengguna komputer di bagian outbound call gedung graha telkom bsd (bumi serpong damai) Tangerang tahun 2011. [Skripsi] Jakarta : Universitas Islam Negeri Syarif Hidayatullah Jakarta ; 2011.

6. Mujaddidi H. R. A. 2012. Analisis faktorfaktor terhadap kejadian computer vision syndrome (CVS) pada pekerja layout editor di CV. "X" Tembalang kota Semarang. Jurnal Kesehatan Masyarakat, 2012 (cited 2014 Jan 17). 1 (2) :731 - 37. Available from: http://ejournals1.undip.ac.id/index.php/jkm

7. Zubaidah H. S. T. Pengaruh Lama Terpapar dan Jarak Monitor komputer terhadap gejala Computer Vision Syndrome pada pegawai negeri sipil di kantor pemerintahan kota Medan. [Tesis] Medan: USU: 2012

8. Hanum, Iis Faizah. Efektivitas Penggunaan Screen pada Monitor Komputer untuk Mengurangi Kelelahan Mata Pekerja Call Centre di PT Indosat NSR. Tesis. Medan: USU, 2008 